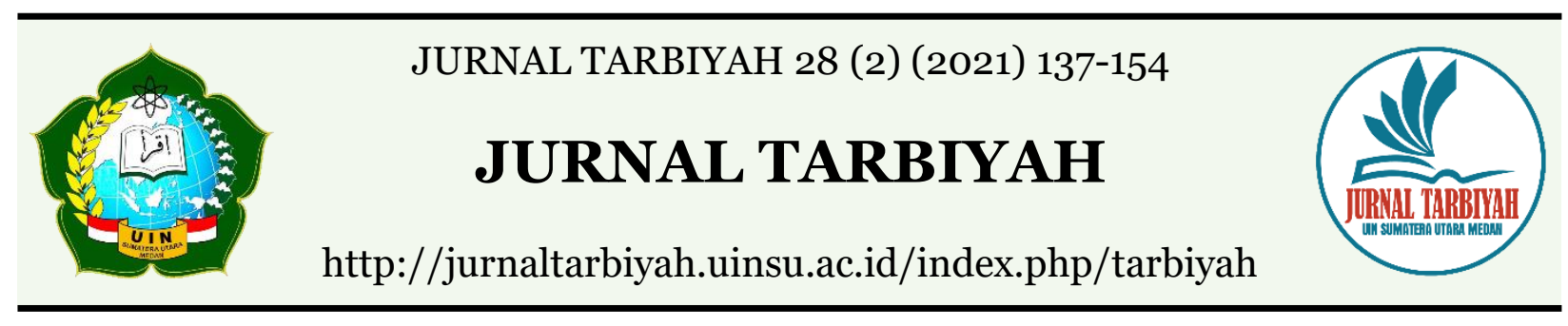

\title{
CHILDREN'S RESPONSE TO ISLAMIC RELIGIOUS LEARNING AT ERWITA SCHOOL EDUCARE CENTER MEDAN
}

\author{
Masganti Sit ${ }^{1}$, Solihah Titin Sumanti², Fatma Gustina ${ }^{3}$ \\ 1,2,3 Universitas Islam Negeri Sumatera Utara, Medan, Indonesia

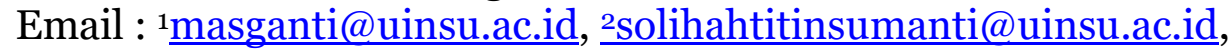 \\ 3fatmasiregar48@gmail.com
}

DOI : 10.30829/tar.v28i2.1158

Accepted: November 4th, 2021. Approved: December 28th, 2021. Published: December 30th, 2021

\begin{abstract}
This study aims to analyze children's responses to Islamic religious learning at the ErwitaEducare Center Kindergarten School in Medan, and Islamic learning at the ErwitaEducare Center Kindergarten School Medan.This research uses descriptive narrative qualitative method. To obtain data, researchers conducted observations, interviews and documentation. In analyzing the data, this research was carried out in stages, namely, data collection, data reduction, data presentation and drawing conclusions in obtaining data.The results in this study indicate that the Islamic Religious Learning of this school emphasizes the Learning of Faith, Learning of Worship, and Learning of Morals. the response to Islamic learning shown by the child is to have a positive response or attitude. This can be seen from some of the responses or attitudes of children in learning, namely (a) Responses / attitudes towards the subject matter of Islamic Religion (b) Responses / attitudes of children towards teachers / teachers (c) Responses / attitudes of children in the learning process in Islamic Religious Learning (d) Cognitive Response (e) Affective Response (f) Conative response. The child shows a positive and responsive response in learning Islamic religion given by the teacher.
\end{abstract}

Keywords:Children's response, learning religious, / attitudes of children 


\section{INTRODUCTION}

Early childhood is children aged o-8 years who have a very big curiosity. However, even though the child has a high sense of desire, the child also has an ego that is still not controlled by the child. Parents are important figures in the growth and development of children, with high children's curiosity, sometimes parents have excessive fears that are indirectly, children's curiosity is inhibited by the anger of parents who do not want to explain the child's curiosity. Education is a process through a method that is developed so that individuals gain knowledge, experience and various things according to their needs (Muhibbin, 2010:10).

Early Childhood Islamic Education is the basic basic education of children's religion, in which the teacher teaches about faith in Allah SWT, piety to Allah SWT, commendable morals, habits to live with the guidance of Islam and always have the confidence to form a character that is liked by many people. . Imam Al Gajalih said it was important to teach children about Islam from an early age because this period is a time of character building that children will carry into adulthood. So the first thing to do is give knowledge to children and educate their hearts or souls with worship. So what must be done is to know or know the child's will, the intelligence he has and what the child wants, then after knowing some of these things it will be easier to educate children and instill general knowledge and knowledge of Islam in children (Fathiyah, 2017: 61).

Islamic religious education in early childhood is important to do from an early age, because if studied in the past, adult students lacked commendable morals because at an early age, these children were not given Islamic religious education from an early age, as seen from manners. children who are not polite and have behaviors that do not reflect good Islamic people. Islamic religious education from an early age is a very strong foundation that makes children live in a straight path and have obedience only to Allah SWT. Then the child will have a religious life that only obeys Allah SWT. If a child grows and develops equipped with the child's knowledge of Islam, the child will have a solid landscape to prevent himself from committing evil acts, which means that the child will be under religious protection because the foundation in his life is based on Islam. Therefore, teachers as educators in schools have a very important role in optimizing children's Islamic knowledge (Ulya: 2015).

Education must have a renewal of Islamic learning that can develop and optimize Islamic learning. So the teacher needs to make learning principles, learning models, learning methods, and media used to develop Islamic Religious Education which aims to 
equip children with Islamic knowledge in a fun way and according to the child's talents. In a research journal involving children as the source of the research, it was concluded in the results of the study that the planting of Islamic characters applied by the hafkan takhasus method could form positive values, such as the value of honesty, working hard, being responsible, diligent, and forming discipline in children. . The journal also explained that it was seen that the development of children experienced a significant increase in the field of Religion Islam knowledge using the hafkah method (Fathiyah, 2017: 65).

Teachers are parents to children when they are at school. Teachers have an important responsibility and role to develop religious values in children. Early childhood is a very appropriate time for a teacher to develop religious aspects that exist in early childhood. which aims to shape the character and character of children based on Islam. An educator must also educate children with the knowledge they have in order to achieve the learning objectives, namely the child has adequate knowledge of the Islamic religion so that one day he can avoid and fortify himself from the nature of evil and become a person who has commendable morals (Fathiyah, 2017). :69).

Erwita Educare Center (EEC) Kindergarten is located in the sub-district of Medan Selayang, Ringroad, Medan, established in 2012. The establishment of the school started with 20 children, divided by 5 people in the PG Play Ground class and 8 people in the KG A class and 7 people in class KG B. This school is a public school that can accept Muslim, Christian and other religious children. In this school there is no major religion because it is almost the same as other religions, for example, 50\% are Christians and 50\% are Muslims. The difference in curriculum in learning causes that Islamic Religious Education in this school has different principles, models, methods and media from other schools. With the knowledge possessed by the teacher, as well as the various differences in Islamic learning that are highlighted by this school, I as a researcher want to see how the children's response to Islamic Religious Education is carried out at the school.

\section{LITERATURE REVIEW}

\section{Early Childhood Religious Development}

a. Child Development in the Qur'an Hadith

In Islam, human development is also one of the important things seen from the many words contained in the Qur'an and Hadith about morals or morals, religious 
abilities, thinking abilities, social abilities, emotional control, and the development of physical form. As the Word of God in Q.S.Ar-Rum/30 verse 54:

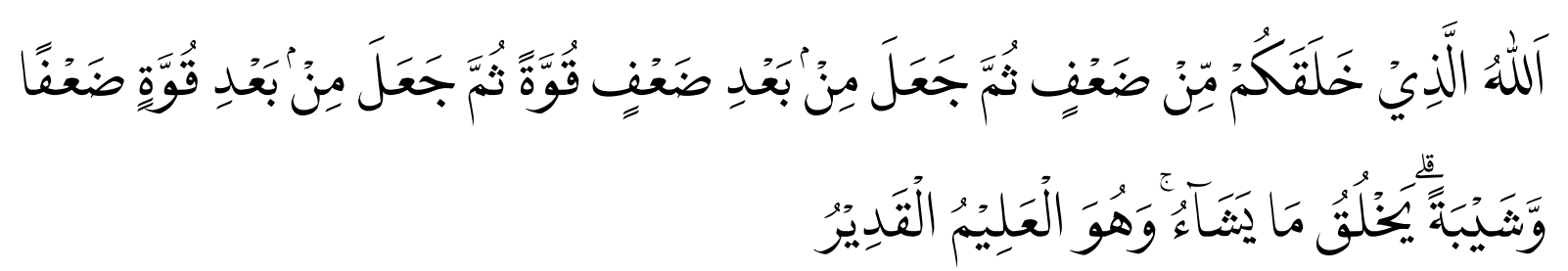

"Allah, it is He who created you from a weak state, then He made after you weak become strong, then He made you weak and gray after you were strong. He creates what He wills and He is All-Knowing, All-Powerful."

In the verse above, it is explained about the physical development of humans starting with childhood, namely a weak state, then becoming a teenager and adult, which is a strong state, and becoming a master, which is a weak state again. Through this verse, Allah explains how humans are born from babies and then become adults at the pleasure of Allah, then Allah also explains the phases of life that will be passed by humans, namely starting with babies, children, then teenagers, early adults, adults, then getting old, and become old. With this verse, humans should become more pious because with the pleasure of Allah, then Allah will make the process easier and in the pleasure of Allah, Allah is All-Knowing what will happen and who controls the universe (Masganti, 2015: 61-62).

b. Physical Development of Children in the Qur'an and Hadith

In the Qur'an Surah Az-Zumar / 39 verse 6 also describes the stages of human creation in the mother's womb, namely:
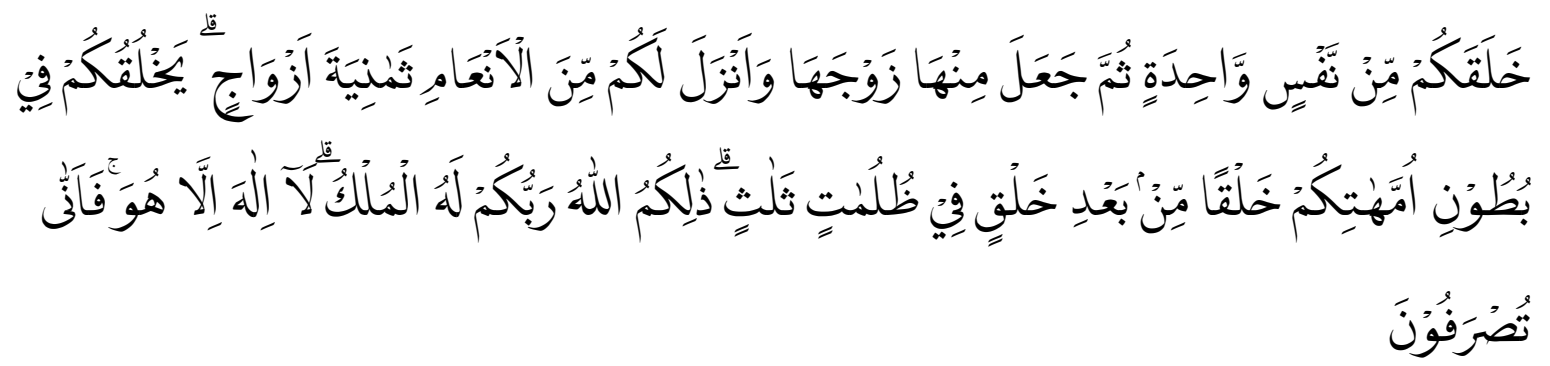

"He created you from a single person, then He made him his wife and He sent down for you eight pairs of cattle. He made you in your mother's womb, event after event in the three darknesses. That is Allah, your Lord, the Lord of the kingdom, there is no god but him; Then how can you be turned away?"

In the book of Al-Qur'an and its Tafsir there is also an explanation of the three phases of darkness when in the womb, first on the membrane that covers the lining 
of the mother's womb so that she avoids decay. After doing research it was found that the membrane has 3 layers. The three layers of the membrane have a function to protect the baby in the mother's womb and help in facilitating birth. In modern biology also revealed 3 stages of embryo formation, namely; pre-embryonic ; first two and a half weeks, embryonic ; until the end of the eighth week, and the fetus ; from the eighth week until birth." The developing branches of science such as genetics and molecular biology have proven the accuracy of the Qur'an which states that in determining sex the role of sperm cells from the male body, while women do not have a role in determining sex. Masganti, 2015: 69-70).

c. Cognitive Development

Islam teaches that when humans are born, they cannot do anything, which Allah then provides with the ability to see, smell, hear, touch, feel and then the heart to gain knowledge (Masganti, 2015: 72). This is stated in Surah an-Nahl/16: 78

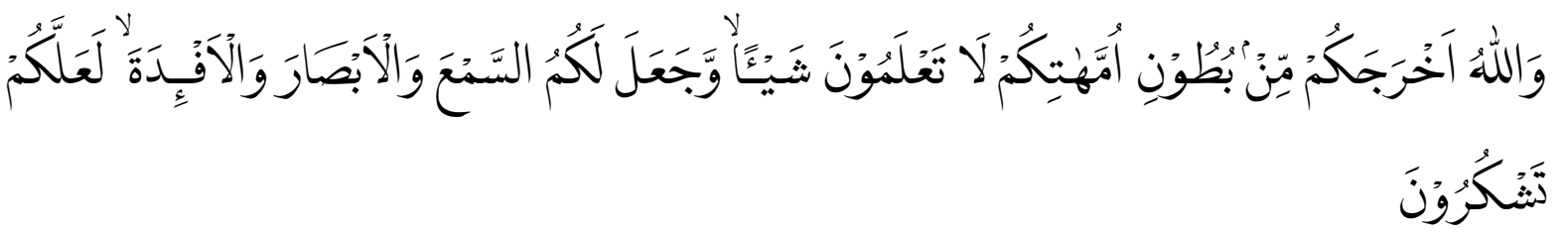

"And Allah brought you out of your mother's womb knowing nothing, and He gave you hearing, sight and hearts, so that you may be grateful."

In Ibn Kasir's interpretation, the human ability to hear, see, and think will develop gradually. The more mature humans are, the more mature their way of thinking will be so that they will be able to distinguish between good and bad and can increase their piety to Allah SWT (Masganti, 2015: 72).

d. Religion Development

In the Qur'an it has also been stated that the nature that already exists in humans will never change. This can be proven from the story of Pharaoh who in the end of his life recognized Allah as God Almighty when he was about to drown because he was chasing Moses (Masganti, 2015:75-76). This story is found in the sura Yunus/10 verse 90:

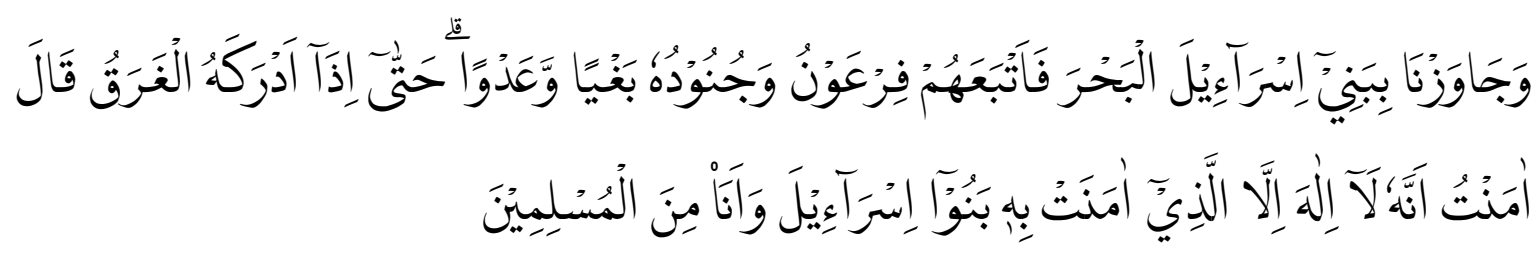


"And we allowed the Children of Israel to cross the sea, then they were followed by Pharaoh and his army, because they wanted to persecute and oppress (them); until when Fir'au had almost drowned he said: "I believe that there is no God but God that the Children of Israel believe in, and I am one of those who surrender (to Allah)".

This shows that Fir'au acknowledged the existence of God even when he had acknowledged himself as God. When no one can help him, his arrogance has sunk and the potential for acknowledging God emerges. Then Allah saved Pharaoh by finding Pharaoh's body as a means of dispelling people's doubts about Pharaoh's death and the truth of the Pharaoh's story. The diversity of the sources of the human soul in obeying God is also caused by the blowing of His spirit on humans. The spirit will always miss its creator and want to return to its origin. Allah also gave humans the ability to do good and bad and they are free to choose to do good or bad.

e. Moral or Moral Development

Allah has provided the ability to recognize good and bad since they were born. This is stated in Surah Asy-Sham verses 7-8:

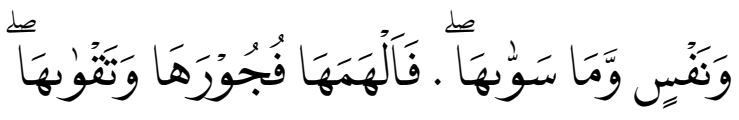

"and the soul and its perfection (of creation). So Allah inspires to the soul (the way) its wickedness and piety."

According to Hamka in Masganti's book (2015:79) the verse states that every human being has also been inspired to be able to choose good and bad and has also been given instructions by Allah SWT. Similar to educating children, parents have a very important role in this matter where parents must be able to honor their children. Giving good names to children so that children will be able to identify themselves according to their names and parents must also be able to position children in a good environment, because the environment will greatly affect the moral and moral development of children. In modern developments as it is today, it is said that one of the factors that play an important role in influencing human morals is the environment in which they live. In Islam it is also stated that the best houses are those near the mosque. The house near the mosque will always give a warning to pray and to keep away from evil and bad treatment. 


\section{Early Childhood Islamic Religious Learning}

According to Aziz, (2001:75) To navigate the life of the world and the provision of the hereafter, children need to receive three groups of educational materials, namely: tarbiyah jismiyah, tarbiyah aqliyah, and tarbiyah spiritualyah or tarbiyah adabiyah. First, tarbiyah jismiyah material. Children will get educational facilities and infrastructure from their parents in the form of facilities to nourish, grow, and refresh their bodies. For the physical needs of children, parents must be selective in providing fulfillment so that there is a balance of worldly and hereafter needs. For example, providing food must be by elevating their morals, namely by keeping them from excessive nature.

Second, the material of tarbiyah aqliyah. Children are given the opportunity to get education and teaching that educates the mind and sharpens the brain. Parents have sufficient opportunities to develop noble character through education in arithmetic, physics, chemistry, and other materials. By applying the integrated curricular method, parents can help children's intelligence as well as raise their morals. Instill sincerity in studying, patience in following the knowledge transfer process. This effort will help children grow intelligently within the scope of gratitude and manifest in noble character both in learning and conveying their knowledge. Furthermore, in the behavior of children's daily life will do it with full responsibility. Third, the material of spiritual tarbiyah or adabiyah tarbiyah. Children are expected to be able to perfect the nobility of character or al ahlaq al karimah.

According to Mansur (2005: 333) the main points of education that must be given to children are Islamic teachings which are broadly divided into three namely: aqidah, worship, and morals.

\section{a. Faith Learning}

In children's lives, the basics of faith must be continuously instilled in children so that every development and growth is always based on the right faith. This can be done by getting children used to saying words that glorify God, exalting, Istigfar, sholawat, short prayers. Children are trained to repeat to do this al.

\section{b. Worship Learning}

Worship education should be introduced as early as possible in children so that they grow into truly pious people, namely people who obey all religious orders and obey all of His prohibitions. For example, children pray, read Iqro or the Qur'an, fast and give charity, this is done continuously so that it is embedded in the child's heart. 


\section{c. Moral Learning}

In order to save and strengthen children's Islamic faith, children's education must be equipped with adequate moral education. So in the context of educating children with morals, besides having to be given the right example, they must also be shown how to respect and so on. For example, getting children to eat together, before eating wash their hands. Children are accustomed to sharing food with friends who do not bring food and helping friends who are in trouble. With this habit, it is hoped that the child will get used to the etiquette of eating.

\section{Children's Responses in Learning}

According to Azwar S, (2011: 85) Responses or attitudes can be learned or are things that can be accustomed, an attitude from one individual to another in an affective domain related to the individual's attitude. Experts say that a person's attitude or response can be predicted to change, provided that the individual has high cognitive management. The affective domain is that there are several aspects, acceptance, response or reaction, assessment, organization. Afactive is an individual's response and attitude about something that is happening or something that is being seen or experienced. So the response or attitude towards something that is happening can be predicted from the things that will be done or the attitude he gives in a situation.

Children who have positive attitudes and responses will foster an interest in learning that grows and develops, so teachers or educators will find it easier to motivate children to learn and children will more easily understand the learning and knowledge provided by the teacher. Therefore, it is important for teachers to assess children's attitudes and responses to learning materials. The response or attitude of the child towards the teacher or teacher. When the learning process is interesting and not boring, the child will like the learning process, so the child will be able to absorb or understand the learning that is being done. Response theory proposed by Katz and StotLaan in a book written by Sutarjo (2014: 79) attitude is a part of a combination of cognitive reactions or responses, namely a perceptual response that is to say something believed, an effective response is a response to a statement of feelings related to one's emotions. Then the last one is, the conative response is a response that does everything by using the impulse from the heart. 


\section{RESEARCH METHOD}

This study uses a descriptive narrative qualitative approach. Descriptive research explains phenomena over a certain period of time. While qualitative research is "an inquiry strategy that emphasizes the search for meaning, understanding, concepts, characteristics, symptoms, symbols and descriptions of a phenomenon, focused and multi-method, natural and holistic, prioritizing quality, using several ways, and presented in a narrative". Qualitative research refers to nonmathematical data analysis. This procedure produces findings obtained through data collected by various means, including interviews, observations, documents or archives, and tests. In this case the author seeks to describe the Response of Early Childhood Islamic Religious Learning at the ErwitaEducare Center Kindergarten School in Medan. In descriptive qualitative research, the data analysis process is carried out throughout the study, namely from the beginning to the end of the study. This qualitative research uses field data analysis techniques using the Miles and Huberman model. The steps of the Miles and Huberman model in qualitative research are as follows (Subagyo, 2017: 90).

\section{RESULTS}

\section{Islamic Religious Learning for Children at Erwita Educare Center Kindergarten School}

Islamic religious education for early childhood is education that provides an introduction to the religion of Allah to children. For example, such as introducing children to the teachings of Allah, such as praying, praying, praying, and various things about the prohibitions and commands of Allah SWT. According to Jumaris in a book written by Rusydi, he describes early childhood education as one of the ways or processes that must be carried out by parents to direct and provide education and provide guidance and direction that aims to shape the character of children who have responsibility for themselves. it means the child makes a good decision, then it is a choice that he can be proud of as a result of hard work, then if the choice has a bad impact then the child must accept and be responsible for the things that have been decided in doing, the role of parents is very important for the formation of children who are ready responsible (Rusydi, 2016:3). 


\section{a. Learning Faith}

In children's lives, the basics of faith must be continuously instilled in children so that every development and growth is always based on the right faith. This can be done by getting children used to saying words that glorify God, exalting, Istigfar, sholawat, short prayers. Children are trained to repeat to do this. Early childhood creed education is a religious learning taught by teachers to children which contains the cultivation of faith in God. (Mustafa, 2009:19). The following is the learning of faith that is carried out to children: Children glorify God

Tabih is purifying oneself by reading Subhanallah, walhamdulillah, walailahaillaloh wallohu akbar, glorifying Allah with all humility. In surah Al-Mu'min Allah says:

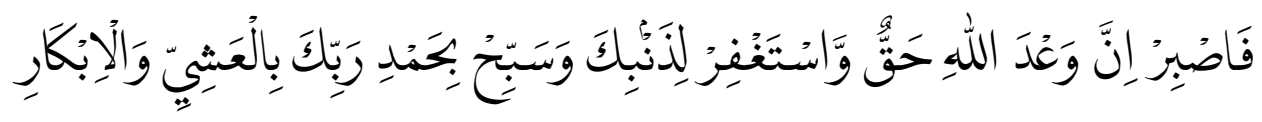

Meaning: So be patient, because Allah's promise is true, and ask forgiveness for your sins and glorify while praising your Lord in the evening and morning. (Q.S AlMu'minin: 55)

So humans must praise and glorify God with all the graces that he has given to humans, such as providing sustenance, good destiny and even bad destiny. Then humans must glorify and glorify God by saying Subhanallah, Walhamdulillah, Walailahahillalloh wallohuakbar. (Zulkarnair, 2011: 194)

According to the teacher who teaches Islam at the EEC Kindergarten, the children from the time they study in the Play Group have been taught Tasbih to Allah even though it is only repeated once a week. In contrast to the KG A class Religion subjects have been held 3 a week, different from other schools, because this school is not based on Islam, so Islamic Religion lessons are held three times a week and children, in a short time the teacher optimizes children's knowledge as well as possible. may include teaching how to glorify God. Then for the KG B class, children also study Religion 3 times a week, but there is a difference, namely children who have KG B can choose an additional class for learning Islam, which is held twice a week, then the children have time for religious learning Islam for 1 hour 30 minutes to study religion, and in this additional time children are usually taught religion in depth. Including this time is used 
by children to learn to read glorify Allah by saying Subhanallah, Walhamdulillah, Walailahahillalloh wallohuakbar.

\section{b. Worship Learning}

In religious learning, habituation and introduction to worship are important and very important elements. Learning to worship is the initial stage in introducing the Creator to children. As the words of the Messenger of Allah, namely: "Tell your children to pray at the age of seven years, and beat him if he does not want to pray at the age of ten years and separate his bed". Children are born with fitra, meaning holy and without color, so it is parents and the environment who give color to children. This means that the learning obtained by children comes from their parents, and their parents provide knowledge and form children's faith and belief in religion, so parents should provide an Islamic environment for children, so that they understand and know Allah as the creator of the universe. (Ulwan, 2015:108)

Children praying is the main thing to do in learning Worship. As we know as Muslims, prayer is the pillar of Islam. Prayer is a direct communication to Allah, and is a command of Allah, prayer is also the second pillar of Islam after performing the creed, so prayer is an element or basic foundation that must be carried out by Muslims. According to an Islamic Religion teacher at the EEC school:Children pray at this school, twice a day, however, in learning the practice of worship, children also pray Duha. The children after lunch do the Zuhur prayer, and the Asr prayer. In reading the prayer readings, the children have been taught the time reading, reading the prayer intentions, Takbiratul Ihrom, reading prayers by reciting Alfatihah, and short surahs, then followed by reciting bowing, prostration and tahiad, then after the children are in Kinder Garden B class the children can already perform the prayer, then the children are also accustomed to praying in congregation, then reading the surah and reading the prayer aloud. So that the teacher hears and can correct the wrong prayer readings.

Based on the observations I made, the children performed the obligatory prayers at school, namely the Zuhur prayer and the Asr prayer, the children read the prayer readings very well, doing the prayer movements was also very good. In my opinion, the Learning of Worship in praying has been successfully carried out at this school. 
c. Moral Education

Morals are a reflection of human self. Good morals are a reflection of human behavior that is carried out properly and takes into account the rules of religious teachings and knowledge that a person has. and vice versa, bad character is a behavior that is not good for someone, without considering the rules of religion and science. So moral education is an important thing to do for children fundamentally and deeply to children, children who have children in accordance with the Qur'an, are lucky children who have been successfully raised by their parents properly and correctly, it is important to play a child's environment that supports improvement children's morals, so that children have a noble and commendable character (Abdullah, 2018:221).

Eating etiquette is an important thing that must be taught to children from an early age, apart from being Muslim, eating etiquette will also be carried out by children for the rest of their life. So when taught properly, children will bring blessings to eat in their lives. The eating etiquette practiced by Muslims, namely, eating with the right hand, washing hands thoroughly before and after eating, reading prayers before and after eating, drinking in three gulps, not blowing hot food but cooling or fanning the food, are all things what the teacher has to do. According to teachers who teach at EEC schools:We have implemented eating etiquette according to the Prophet's advice, namely washing food before eating and after eating, eating with the right hand, then drinking sitting and in three gulps, fanning hot food and not blowing, then reciting prayers before and after eating. And this has been done by the child and taught by the teacher since the child was in the playgroup class.

In my observations at school, children have etiquette to eat and apply the things that have been described by the teacher. So in my opinion the eating etiquette carried out by the teacher is very good and the children have good eating etiquette.

\section{Responses to Children's Attitudes and Behaviors in Islamic Religious Learning in Kindergarten ERWITA EDUCARE CENTER (EEC)}

Response is something that is learned and is a form and reaction to something that is received and faced by the individual. Response or attitude is something that can be learned and changed in a response or problem. Someone who already has knowledge and knowledge that eats a lot of responses in dealing with something will be different from other humans who face the same problem. Some responses in the affective domain consist of several aspects, namely: acceptance, reaction in a matter, 
grouping, and internal. Affective is an attitude and response to something that is happening. So the child's response in something that happens can be divided into several reactions, namely, happy , happy, sad and feel nothing. (Azwar S, 2020: 189)

There are several things that were investigated from the response to children's learning carried out at Erwita Educare Center Kindergarten, namely:

a. Response / attitude towards the subject matter of Islam

Children have critical thinking, namely children who are responsive and have many questions about what children hear, experience, feel and see. In religious learning, children are accustomed to religious learning, so children have questions about religious knowledge that they know, see and use. According to the EEC Teacher:When learning materials for Islam, for example, when we learn about Noah's Sirah, we make an Ark from origami paper, then we name it as Noah's Ark, the children are very enthusiastic about knowing the story of the ark, in this case the child is very critical, the child asks questions. the things that happened to Noah's Ark.

In the observations that I did the teacher gave learning and knowledge to children in a very creative way, until the children were very critical in learning the Religion, for example when the activity of Making Noah's Ark, the children were led to make an Ark from origami, after that the children in tell stories and teachers while explaining and asking questions, making children critical of learning the Islamic religion.

b. Children's response/attitude towards the teacher/teacher

The response or attitude given by children in learning is an important thing to see for observation or evaluation in developing learning to be more effective for children. According to one teacher, that the children in the EEC school:

"Children in Islamic learning always give a good response to the teacher, for example, the child is always orderly and listens carefully, then the children here also if the teacher cannot attend or experience delays always ask about the teacher".From the questions asked by children to teachers in the field of religious studies, it was seen that children really liked religious learning. The children are also very focused and listen carefully to the teacher in learning the religion. 
c. Children's responses/attitudes in the learning process in Islamic Religious Learning

In early childhood development, the independence of children is an important thing to do. Not only in taking care of themselves, children's independence is trained from the way children do Islamic religious education tasks given by the teacher, because independence is the main foundation so that children can face the future well. According to the EEC teacher:In learning Islamic religion, children who have been trying to perform ablution can perform ablution themselves but are still monitored by the teacher, then in writing or doing crafts related to learning Islamic religion, children must do it themselves after being given a tutorial or learning by the teacher.

\section{d. Cognitive Response}

In learning, it aims to provide information to children, in the learning process, the absorption capacity of the child or child must be able to capture the information provided by the teacher, including in Islamic religious learning, the child must be able to capture the information provided by the teacher. According to the teacher who teaches Islamic studies at EEC:Islamic Religion learning is a lesson that children should be able to absorb and capture the information provided by the teacher, in this school, children are given learning materials then after being explained, there are questions and answers given to children, in addition to training children's focus In learning, question and answer also aims to see the response or attitude of the child in capturing the information provided, or the child asking questions.

\section{e. Affective Response}

In learning, children must have a sense of pleasure in receiving learning. Learning with happy reactions from children will make children know and remember learning. The sense of pleasure and joy that children get in learning Islam will make children know more quickly so that they can achieve learning goals, namely children receive information or knowledge provided by the teacher more easily. According to a teacher who teaches at EEC:Children's joy is our goal in learning apart from providing knowledge to children, joy and pleasure are things that we consider, therefore we always sing together, make crafts, and read Iqro by packaging learning creatively and as well as possibl . 


\section{f. Conative response}

In learning Islam, encouragement from within yourself or the initiative of the child is needed. Islamic religious learning, if it starts with the encouragement of the child or the child has the initiative to do something, it can be said that learning is successful. According to a teacher who teaches at EEC:In Islamic learning, because it is directly related to the activities that children will do in their daily lives, it can be seen that there is an inner urge for children to do something, such as praying after the Azan, taking ablution and even praying after praying, after learning Religion Islam, I often pay attention to what children do, and I see some children have an inner urge to do good.

\section{CONCLUSION}

1. From the explanation above, the researcher concludes that the learning carried out at the Erwita Educare Center Kindergarten has gone very well, it can be seen from some of the instruments described by the author, these aspects are of good value. with developmental aspects and things that a teacher must do in developing Islamic knowledge for early childhood. the learning carried out by the teacher is very creative, so that the learning presented by the teacher is responded well by the child. So as a researcher who observes, conducts interviews and documentation, concludes that Islamic learning is in accordance with the development of the child's religion, and children have good knowledge in learning the Islamic religion.

2. In terms of what has been described above, from the results of observations, interviews and documentation conducted by researchers, the researchers concluded that children had a positive response to the learning carried out by the teacher. Then to get a positive response from children, teachers play an active role and provide creative learning and motivate children in learning Islam. The success of learning Islam can be seen from the response of the child and the attitude of the child in everyday life. The researcher saw that the children were very enthusiastic about praying, reading the daily prayers and reading the surahs that were memorized by the children. Seen children are very enthusiastic in learning Islam. 


\section{REFERENCES}

Ananda, Rizki. "Implementasi Nilai-nilai Moral dan Agama pada Anak Usia Dini." Jurnal Obsesi: Jurnal Pendidikan Anak Usia Dini, 2017: Volume 1 Issue 1. Ananda, Rusydi. Inovasi Pendidikan,. Medan: CV. Widya Puspita, 2016. Andayani, Abdul Madjid dan Dian. Abdul Madjid dan Dian Andayani, Pendidikan Agama Islam Berbasis Kompetensi Konsep dan Implementasi Kurikulum 20Pengembangan Anak Usia Taman Kanak-kanak. Jakarta: Grasindo, 2004.

Arikunto, Suharsimi. Manajemen Penelitian. Edisi Revisi. Jakarta: PT. Rineka Cipta, 2005 .

Astuti, Wiji. "Model Quantum Learning untuk Meningkatkan Hasil Belajar Pecahan," Briliant.” Jurnal Riset dan Konseptual, 2017: Volume 2 Nomor 2.

Aziz, Abdul. "Implementasi Inovasi pada Model-model Pendidikan Anak Usia Dini di Taman Pengasuhan Anak (TPA) Serama Kementerian Kesehatan RI.” Jurnal Pendidikan Anak Usia Dini , 2017: Volume 11 edisi 2 .

Azmi, Muhammad. Pembinaan Akhlak Anak Usia Pra-Sekolah. Yogyakarta: Venus Corporation, 2006.

Bukhari, Imam. "Kitab Shahih Buhari,Bab al-Jana’iz, bab ma qila aulad al-musyrikin.” Juz 5, 1296: 181.

Creswell, J.W. "Reseach design: Penerapan Metode Kualitatif, Kuantitatif dan Campuranr.” Yogyakarta: Pustaka Belajar, 2016.

Hamalik, Oemar. Proses Belajar Mengajar. Jakarta: Bumi Aksara, 2007.

Hernowo. Menjadi Guru yang Mau dan Mampu Mengajar Secara Menyenangkan. Bandung: Grafindo, 2015.

Indonesia, Peraturan Menteri Pendidikan dan Kebudayaan Republik. Standar Nasional Pendidikan Anak Usia Dini. 2014.

Isbandi, Adi. Psikologi Pekerjaan social. Jakarta: Raja Grafindo, 2019.

Kebudayaan, Menteri Pendidikan dan. Peraturan menteri Pendidikan dan Kebudayaan Republik Indonesia Nomor 137 Tahun 2014 Tentang Standar nasional Pendidikan Anak Usia Dini. Jakarta: Menteri Pendidikan dan Kebudayaan RI, 2014.

Khadijah. Media Pembelajaran Anak Usia Dini. Medan: Perdana Publishing, 2015.

-. Pengembangan Kognitif Anak Usia Dini. Medan: Perdana Publishing, 2016. Kholidah, Ahmad Munjin Nasih dan Lilik Nur. Metode dan Teknik Pembelajaran Pendidikan Agama Islam. Bandung: Refka Aditama, 2018. 
Maisarah. Matematika dan Sains Anak Usia Dini. Medan: Akasha Sakti, 2018.

Mansur. Pendidikan Anak Usia Dini dalam Islam. Yogyakarta: Pustaka Pelajar, 2005.

Masganti. Psikologi Perkembangan Anak Usia Dini. medan: perdana publishing, 2015.

Moleong, Lexy J. Metodologi Penelitian Kualitatif. Bandung: Rosada Karya, 2010.

Mudhaffir. Teknologi Instruksional: Sebagai Landasan Perencanaan dan Penyusunan

Program Pengajaran. Bandung: PT. Remaja Rosdakarya Offset, 1999.

Mulyasa, E. Kurikulum yang Disempurnakan. Bandung: Remaja Rosdakarya, 2006.

Mushoffa, Aziz. Untaian Mutiara Buat Keluarga Bekal Bagi Keluarga dalam

Menapaki Kehidupan. Yogyakarta: Mitra Pustaka, 2001.

Nasional, Menteri Pendidikan. Peraturan Menteri Pendidikan Nasional Nomor 58

Tahun 2009 Tentang Standar Pendidikan Anak Usia Dini. Jakarta: Menteri

Pendidikan Nasional, 2009.

Nicholl, Colin Rose dan Macolm J. Accelerated Learning for the 21st Century (Cara Belajar Cepat Abad XXI). Bandung: Nuansa Cendekia, 2017.

Nurfaizah, Mhd.Habibu Rahman. "Inovasi pengembangan nilai-nilai agama Pada anak usia dini." Qurroti, Jurnal Pendidikan Anak usia Dini, 2020: Vol. II No.2Oktober .

Pohan, Sermal. Strategi Pendidikan Anak Usia Dini Dalam Membina Sumber Daya Manusia Berkarakter. Medan: Perdana Publishing, 2016.

sarlito, Sarwono. Psikologi Remaja. Jakarta: Rajawali Press, 1991.

senjaya, Wina. Strategi Pembelajaran. Jakarta: Kencana Prenada media Group, 2006.

Shihab, M. Quraissh. Tafsir Al-Qur'an. Jakarta: Lentera Hati, 2002.

Silberman, Melvin L. Active Learning 101 Cara Belajar Siswa Aktif, (Terjemah Raisul Muttaqinsa. . Bandung : Nusa Media dan Nuansa, 2004.

Slavin. Educational Psicology. America: Allyn \& bacon united stat, 2009.

Soenarjo. Al Qur'an dan Terjemah. Jakarta: Departemen Agama RI, 2003.

Sugiyono. Metode Penelitian Pendidikan Pendekatan Kuantitatif, Kualitatif, dan R\&D . Bandung: Alfabeta , 2006.

Suyanto, Slamet. Dasar-dasar Pendidikan Anak Usia Dini. Yogyakarta: Hikayat, 2005. Syah, Muhibbin. Psikologi Pendidikan dengan Pendekatan Baru (edisi revisi).

Bandung: PT Remaja Rosdakarya Offset, 2010.

Ulya, Machya Afiya. "Penanaman Karakter Islami melalui Program Hafalan Takhasus di SD Hj. Isriati Baiturrahman 2 Semarang Tahun ajaran 2015/2016.” Skripsi, 
Masganti Sit et al./ JURNAL TARBIYAH 28 (2) (2021) 137-154

2016: Universitas Islam Negeri Walosongo Semarang: Fakultas Ilmu Tarbiyah dan Keguruan.

Usman, Basyiruddin. Metodologi Pembelajaran Agama Islam. Jakarta: Ciputat Pers, 2018.

Zain, Syaiful Bahri Djamarah dan Aswan. Strategi belajara Mengajar. Jakarta: Rineka Cipta, 2002. 